\title{
PERILAKU MAHASISWA PENGGUNA VAPOR DAN DAMPAKNYA PADA KESEHATAN
}

\author{
Ovi Tri Ariyani ${ }^{1}$, Mury Ririanty ${ }^{2}$, Iken Nafikadini ${ }^{3}$ \\ ${ }^{1,2,3}$ Fakultas Kesehatan Masyarakat Universitas Jember, Indonesia; \\ Email (ovitriariyani@yahoo.com¹, muryririanty@yahoo.com², \\ iken.nafikadini@gmail.com ${ }^{3}$ )
}

\begin{abstract}
Vapor today has become a phenomenon among the public, especially students. This is in line with the finding of Jember University students who are members of the user community vapor 4 and 3 groups that selling tools and vapor-liquid in social media, especially Facebook. The factors of students using the vapor are following the development of lifestyle, steam vapor generated numerous and unique, has the flavors and can eliminate the addiction to conventional cigarettes. This study aims to analyze the behavior of students who use vapor and its impact on health. The research method used is qualitative with the type of phenomenological research. This research was conducted on 4 students at the University of Jember. The results of this study indicate that the behavior of vapor use by the first informant is determined by lack of knowledge about the impact of vapor for health, a negative attitude that considers vapor safer than cigarettes, vapor as a tool to stop smoking, and personal references especially friends and youtube in making decisions using vapor. With the result that, the main informants will continue to use vapor because of lack of knowledge, negative attitudes, and strong of personal references.
\end{abstract}

Keywords: students, vapor, the impact on health.

\section{PENDAHULUAN}

Saat ini telah timbul fenomena baru, yaitu adanya penggunaan rokok elektrik $^{[1]}$. Sekitar $10,9 \%$ penduduk Indonesia telah mendengar tentang rokok elektrik dan sekitar 0,3\% menggunakannya. Sebagian besar pengguna dari rokok elektrik berusia 1524 tahun dan 25-44 tahun (GATS tahun 2011, Global Adults Tobacco Survei) (Desideria, 2016). Rokok elektrik telah berkembang hingga pada generasi ketiga yang menggunakan sistem tangki yang dikenal dengan istilah vape atau vapor. Vapor adalah alat bertenaga listrik yang berfungsi untuk mengganti zat-zat kimia menjadi bentuk uap dan mengalirkan ke paru-paru (BPOM, 2015). Zat kimia seperti nikotin yang bercampur dalam campuran gliserin, propilen glikol atau humektan lainnya dengan air dan disediakan dalam cartridge atau tank yang terkadang bisa diganti atau refillable. Proses dari mengubah larutan menjadi uap biasanya diaktifkan dengan 
tindakan menghirup perangkatnya, atau 'vaping'(Brown et al., 2014).

Vapor telah membuat banyak kalangan muda seperti pelajar SMA dan juga mahasiswa bahkan anak-anak mencoba menggunakan vapor. Vapor dirasa lebih aman dan stylish serta memiliki sensasi merokok seperti rokok konvensional sehingga banyak kalangan perokok beralih ke vapor dan juga beberapa pihak berpendapat bahwa dengan menggunakan vapor dapat membantu mengurangi ketergantungan penggunaan rokok konvensional dan juga alat untuk menghentikan kebiasaan merokok (BPOM, 2015). Namun, dalam penelitian yang dilakukan oleh Vickerman et. al., menghasilkan tingkat penghentian merokok ditemukan secara statistik lebih rendah pada orang yang menggunakan vapor dibandingkan dengan mereka yang tidak menggunakan vapor(Nayir et al., 2014). Selain itu, pengguna vapor ingin menggunakan vapor karena melihat orang disekitarnya juga menggunakan dan tertarik karena rasa dan uap yang dihasilkan banyak (Indra et al., 2015).

Kenyatannya vapor dapat memberikan efek yang merugikan bagi kesehatan seperti dampak yang ditimbulkan karena cairan vapor, adanya nikotin dapat menimbulkan rasa adiksi (BPOM, 2015); paparan nikotin pada ibu hamil dapat membahayakan kesehatan janin dalam kandungan, pada bayi menyebabkan berat badan lahir rendah (BBLR), kelahiran prematur, bayi lahir mati (stillbirth), dan sindrom kematian bayi mendadak (SIDS); remaja muda yang menggunakan vapor dapat mengalami gangguan kognitif dan perilaku, termasuk berdampak pada ingatan dan perhatian; anak atau orang dewasa yang menelan, menghirup, atau menyerap cairan vapor melalui kulit atau mata dapat mengalami keracunan yang ditandai dengan gejala mual, muntah, kejang, dan depresi pernapasan. Bahkan cairan nikotin yang tertelan dapat menyebabkan kematian, terutama pada anak-anak (Erikania, 2017); dapat menyebabkan iritasi pernafasan seperti asma dan sesak dada akibat adanya propilen glikol; bahan perisa (flavoring) yang digunakan dapat membahayakan kesehatan dikarenakan tidak semua bahan perisa aman untuk inhalasi (BPOM, 2015).

Terdapat beberapa dampak lain dari penggunaan vapor seperti, dengan memasukkan bahan berbahaya ilegal (mariyuana, heroin, dan lain-lain) sehingga vapor dapat disalahgunakan 
(BPOM, 2015) seperti, Kepala Badan

Narkotika Nasional Kota (BNNK)

Surabaya menemukan adanya peredaran narkoba yang dicampur dengan cairan vapor. Efek yang diperoleh dari penggunaan narkotika cair mirip dengan menggunakan ganja (Prasetyo, 2017); resiko bertambahnya perokok pemula; memiliki risiko bertambahnya perokok ganda yaitu pengguna rokok konvensional dan juga vapor secara bersamaan (dual user); dengan adanya klaim bahwa vapor aman digunakan maka akan adanya risiko mantan perokok untuk kembali merokok, merenormalisasi perilaku merokok; vapor dapat mengganggu kebijakan KTR (Kawasan Tanpa Rokok) (BPOM, 2015) dan menyebabkan luka bakar akibat meledaknya vapor dalam mulut hal ini dikarenakan cairan vapor dan voltase pada baterai memiliki komponen yang berbahaya dan akan semakin berbahaya jika pada tegangan yang tinggi sehingga dapat menimbulkan percikan api (Setyanti, 2014; Lorensia et al., 2017).

Saat ini pengguna vapor telah memasuki Kabupaten Jember, hal ini dapat dilihat terdapat delapan store vapor yang berada di Kabupaten Jember khususnya disekitar daerah Universitas Jember yang mana Universitas Jember menjadi rujukan tempat pembelajaran dikawasan timur daerah Jawa Timur. Studi pendahuluan yang telah dilakukan peneliti kepada 112 mahasiswa Universitas Jember secara acak menunjukkan bahwa sebanyak 20 mahasiswa (19\%) sebagai perokok. Sebanyak 31 mahasiswa (28\%) pernah menggunakan vapor dan sebanyak 4 mahasiswa (20\%) beralih dari rokok ke vapor. Selain itu peneliti juga telah melakukan observasi melalui media sosial dan menemukan sebanyak empat komunitas pengguna vapor yang terdapat mahasiswa Universitas Jember sebagai anggotanya yaitu Vapor Community Jember, Jember Selatan Vapor Community, Jember Vapor Society, dan Vapers Jember dan juga ditemukannya mahasiswa Universitas Jember yang tergabung pada tiga grup facebook yang melakukan jual beli alat maupun cairan vapor. Adapun grup facebook tersebut yaitu, Jual-beli vapor/vape area Jember, Jual-beli vape baru/bekas wilayah Jember, dan Jember vape Market Est. Tujuan dari penelitian ini adalah untuk mengetahui perilaku mahasiswa yang menggunakan vapor dan dampaknya pada kesehatan, dengan melihat pengetahuan, sikap, personal 
references, dan juga tindakan dari mahasiswa yang menggunakan vapor.

\section{METODE PENELITIAN}

Metode penelitian yang digunakan adalah kualitatif dengan jenis penelitian fenomenologi. Penelitian ini dilakukan di Universitas Jember, salah satu perguruan tinggi di Kabupaten Jember. Informan utama pada penelitian ini sebanyak empat orang dan informan kunci sebanyak satu orang yaitu karyawan penjual vapor. Informan utama didapatkan dari informan kunci dan mendapatkan informan utama selanjutnya melalui teknik snowball.

Data primer pada penelitian ini diperoleh melalui studi pendahuluan pada mahasiswa Universitas Jember penyebaran angket, wawancara mendalam, observasi, pengambilan dokumentasi dan triangulasi teknik. Sedangkan data sekunder pada penelitian ini adalah penelitian terdahulu, jurnal penelitian, artikel online terkait vapor dan dampaknya pada kesehatan. Analisis data pada penelitian ini menggunakan thematic content analysis. Uji kredibilitas data pada penelitian ini dengan menggunakan triangulasi teknik yang dilakukan dengan melakukan wawancara mendalam, observasi, dan dokumentasi untuk sumber data secara serempak. Sedangkan, uji dependabilitas dilakukan oleh dosen pembimbing dengan mengaudit proses penelitian secara keseluruhan.

\section{HASIL DAN PEMBAHASAN}

Pengetahuan informan utama dilihat dari manfaat dari menggunakan vapor, cairan vapor yang mengandung nikotin, dan cara mengatasi dampak yang disebabkan menggunakan vapor adalah kurang. Sebagian informan utama mengatakan bahwa menggunakan vapor dapat memberikan manfaat untuk berhenti merokok dan mengurangi konsumsi merokok.

"...Saya bisa berhenti merokok." (IU 2, Laki-laki, 22 tahun).

Informan utama 2 mengatakan bahwa manfaat yang didapat dari menggunakan vapor yaitu dapat berhenti merokok. Namun, sebuah survei yang disponsori oleh produsen vapor menemukan bahwa hanya $1 \%$ dari pengguna vapor yang mampu bertahan secara permanen untuk berhenti merokok. Hal ini adalah bukti bahwa vapor sering digunakan untuk penggunaan ganda (menggunakan vapor dan rokok konvensional), bagi mantan perokok, vapor digunakan sebagai suplemen yang digunakan misalnya di tempat-tempat dengan larangan 
merokok, dan oleh perokok yang berencana untuk berhenti merokok tetapi memilih beralih ke vapor, vapor digunakan dalam jangka panjang, dengan demikian akan meruntuhkan penghentian total untuk berhenti merokok (Pisinger, 2014). Manfaat lain yang didapat menurut informan 3 yaitu untuk bersenang-senang.

"Ga ada sih. Ya untuk bersenangsenang aja." (IU 3, laki-laki, 21 tahun).

Adanya nikotin menyebabkan efek adiktif. Efek nikotin dapat menimbulkan kecanduan karena adanya interaksi antara nikotin dengan reseptor kolinergik nikotin di otak yaitu nicotinic acerylcholune receptors ( $\mathrm{nAChRs)}$ di daerah mesolimbik dopamin system di Ventral Tegmental Area (VTA) neuron yang mengawali aktivasi Central Nervus System (CNS) termasuk system mesoaccumbens dopamine. Reseptor nikotinin mengatur pelepasan dopamin. Nikotin mengubah aktivitas VTA untuk meningkatkan sekresi dopamin. Dopamin yang dilepaskan dapat berperan dalam pengontrolan fungsi aktivitas lokomotorik kognisi, emosi, reisformenpositif, serta regulasi endokrin. Akibat dari pelepasan dopamine timbul perasaan nyaman sehingga dapat membuat kesenangan (Lorensia et al., 2017).
Sebagian besar informan utama juga mengatakan bahwa tidak mendapatkan manfaat dari menggunakan vapor. Sebuah penelitian yang pada 106 pasien yang didiagnosis dengan kanker leher dan kepala yang menunjukkan bahwa vapor tidak memberikan manfaat apapun ketika digunakan untuk berhenti merokok (Nayir, 2016). Hasil penelitian ditemukan bahwa informan utama telah merasakan dampak dari penggunaan cairan vapor yang bernikotin seperti dehidrasi, pusing dan kecanduan yang merupakan efek merugikan bagi informan utama.

Sebagian informan utama telah merasakan dampak dari menggunakan vapor yaitu pusing dan degidrasi seperti ungkapan informan utama 4.

"Cuman kalau kebanyakan ya gara-gara makek terus-terusan bisa mengganggu ke otak, kayak pusing, migraine gitu, dehidrasi." (IU 4, Lakilaki, 22 tahun).

Pusing yang dialami oleh informan utama dikarenakan informan utama telah mengalami dehidrasi yang berat dan tetap menggunakan vapor dengan kandungan nikotin (Yusepi, 2017). Penggunaan vapor dapat menghasilkan efek samping salah satunya otak kekurangan oksigen. Meningkatkan kadar karbon monoksida yang berada di 
otak dan darah dapat menghambat oksigen dalam penyerapannya sehingga membuat rasa pusing dan kepala menjadi berat (Allteppos, 2016).

Sebagian besar informan utama hanya mengetahui bahwa cara mengatasi dampaknya dengan banyak meminum air.

"Oh mungkin ya kalau awal-awal itu dehidrasi. Cepet kering ke tenggorokan. Harus banyak minum air." (IU 3, Laki-laki, 21 tahun) “...Jangan terlalu berlebihan aja kalau makek...” (IU 2, laki-laki, 22 tahun).

Adanya propylene glycol dapat menyebabkan dehidrasi dengan ditandai rasa haus yang kuat dan juga bibir yang kering, maka dianjurkan untuk minum air sebanyak 2 gelas kemudian istirahat selama 30 menit lalu dilanjutkan untuk menggunakan vapor jika ingin menggunakan (Yusepi, 2017). Tidak berlebihan dalam menggunakan vapor. Melakukan inhale dan ex-hale dengan wajar (Allteppos, 2016) ${ }^{]}$. Pengetahuan yang kurang ini akan menyebabkan informan utama tetap menggunakan vapor tanpa mempertimbangkan dampak pada kesehatan seperti meningkatkan denyut jantung, tekanan darah dikarenakan adanya nikotin. Asma, sesak dada, nyeri otot, sakit tenggorokan dikarenakan adanya propilen glikol dan juga jika dampak ini terjadi berkelanjutan maka akan menyebabkan dampak yang lebih besar pada kesehatan dalam jangka panjang. Sikap seluruh informan utama menunjukkan sikap yang negatif. menganggap bahwa vapor lebih aman dari rokok walaupun ada keraguan, seperti yang diungkapkan oleh informan utama 3 sebagai berikut:

"Kayaknya sih lebih aman vapor kan uap bukan asap kayak rokok. Kayaknya sih ya. Walaupun sama-sama ada nikotinnya, tapi kan ini perbotolnya, berapa, bukan permilinya nikotinnya..." (IU 3, laki-laki, 21 tahun).

Pernyataan informan utama 3 yang menganggap bahwa vapor lebih aman dari rokok tidak tepat dikarenakan kandungan cairan vapor dan vapor dikarakterisasi dengan jumlah propilen glikol yang tinggi, dan kadang gliserin, nikotin dan rasa. Banyak vapor mengandung informasi yang menyesatkan/hilang pada bagian bahan produk, terutama nikotin, dan banyak penelitian menemukan zat berbahaya: partikel halus/partikel yang sangat halus, sitotoksisitas, logam berbahaya, nitrosamine karsinogenik spesifik tembakau dan karbonil di sebagian besar sampel, dan beberapa sampel yang lain (Pisinger et al., 2014). Selain itu, Food and Drug Administration (FDA) 
juga menemukan sampel yang memiliki jumlah nikotin dan jejak racun bahan kimia yang bervariasi, termasuk bahanbahan karsinogen. Temuan ini mendorong FDA untuk mengeluarkan peringatan tentang potensi risiko kesehatan terkait dengan vapor (Johnson et al., 2014).

Informan utama menganggap vapor sebagai salah satu alat untuk berhenti merokok seperti yang diungkapkan oleh informan utama 2.

"Ya saya sendiri pakek vapor buat berhenti merokok. Ya saya setuju sih. Tapi temen saya ada kok yang pakai dua-duanya." (IU 2, laki-laki, 22 tahun).

Senada dengan itu, terdapat sebuah berita yang dilansir pada detikhealth.com bahwa terdapat salah satu pengguna vapor selama 6 bulan yaitu Ricky yang berusia 26 tahun namun masih menghisap rokok konvensional. Sebelum menggunakan vapor, Ricky bisa menghabiskan satu setengah bungkus dalam sehari namun saat ini satu bungkus bisa habis dalam waktu dua minggu. Meskipun Ricky menganggap hal tersebut merupakan sebuah kemajuan untuk berhenti merokok (Detikhealth, 2014).

Informan utama mengatakan bahwa vapor merupakan hal yang baru sehingga dampak dari penggunaan vapor masih belum diketahui meskipun adanya kekhawatiran akan dampaknya bagi kesehatan dalam jangka panjang dan sebenarnya informan utama telah merasakan dampak dari menggunakan vapor seperti dehidrasi, pusing, dan juga kecanduan. Dampak ini dianggap hal yang remeh dikarenakan informan utama tidak sampai harus pergi ke dokter ataupun melakukan cek kesehatan, sehingga membuat informan utama merasa bahwa masih belum merasakan dampak dari menggunakan vapor. Tak hanya itu, dampak yang dihasilkan dari menggunakan vapor yaitu memberikan efek kronis seperti penyempitan atau pengentalan darah, iritasi pernafasan, asma, mengi, sesak dada, penurunan fungsi paru-paru, dan obstruksi jalan pernafasan (BPOM, 2015).

Sikap yang mengarah ke negatif ini menyebabkan informan utama tetap menggunakan vapor. Namun informan utama juga menunjukkan sikap yang positif mengenai fenomena pengguna vapor saat ini yang kebanyakan karena vapor merupakan hal yang baru sehingga banyak yang ingin tahu tentang vapor bahkan anak dibawah umur banyak yang menggunakan vapor.

"Rame, banyak yang pakek. Karna harga liquid sekarang murah-murah. Terus sekarang liquid sudah legal. Tapi 
negatifnya, itu sih, banyak anak kecil yang udah nyoba-nyoba, anak kecil yang dibawah umur gitu..." (IU 1, Laki-laki, 22 tahun).

Pernyataan yang diungkapkan oleh informan utama 1 mewakili pernyataan seluruh informan utama mengenai banyaknya anak dibawah umur yang menggunakan vapor. Padahal vapor ditujukan kepada orang-orang yang berusia 18 tahun keatas. Informan utama 3 mengatakan bahwa seseorang yang mempengaruhinya untuk menggunakan vapor (personal references) adalah teman.

"Ya karena temen sih awalnya makek." (IU 3, Laki-laki, 21 tahun).

Penelitian ini menemukan teman dan youtuber merupakan personal references bagi informan utama untuk menggunakan vapor. Adapun cara personal references mempengaruhi informan utama untuk menggunakan vapor yaitu dengan cara memberikan pinjaman vapor miliknya. Beberapa informan utama mengetahui bahwa terdapat teman yang mengalami dampak penggunaan vapor bagi kesehatan, namun informan utama masih tetap menggunakan karena didukung dengan adanya informasi mengenai vapor lebih aman daripada rokok yang dijelaskan oleh youtuber. Paparan informasi mengenai vapor berasal dari media elektronik dan teman seperti internet, jika dibandingkan dengan media lain seperti televisi dan juga radio. Promosi menggunakan vapor dimulai di media internet, banyak remaja terpapar oleh iklan vapor menyebabkan peluang yang tinggi bagi remaja menggunakan vapor (Putra et al., 2017).

Vapor masuk ke Indonesia pada tahun 2014 akhir sampai 2015 mengalami penurunan. Tahun 2016 meningkat kembali. Informan kunci mengatakan bahwa vapor memasuki Jember pada tahun 2015. Hal ini juga diungkapkan oleh sebagian informan utama bahwa awal informan utama menggunakan vapor pada tahun 2015 dan 2016. Seluruh informan utama membeli alat vapor maupun cairan vapor secara langsung di store vapor, namun sebagian informan juga melakukan pembelian secara online. Alasan informan utama menggunakan vapor yaitu karena ingin berhenti merokok dan mengurangi penggunaan rokok, tertarik akan adanya varian rasa cairan vapor dan uap yang dihasilkan bahkan karena mengikuti tren saja, seperti yang diungkapkan informan utama 4 berikut:

"Pengen ngerubah kebiasaan merokok. Keterpaksaan mengikuti tren." (IU 4, laki-laki, 22 tahun). 
Tindakan mahasiswa pengguna vapor ini didasari oleh pengetahuan, sikap, dan juga personal references. Pengetahuan merupakan faktor yang dapat mempengaruhi perilaku seseorang (Ririanty, 2017). Hasil dari penelitian ini menunjukkan bahwa pengetahuan informan adalah kurang, informan mengatakan bahwa menggunakan vapor dapat memberikan manfaat untuk berhenti merokok dan megurangi konsumsi merokok, meskipun informan utama telah merasakan dampak dari menggunakan cairan vapor yang bernikotin seperti dehidrasi, pusing dan kecanduan. Sikap merupakan hal yang paling penting dalam psikologi sosial untuk menentukan perilaku seseorang (Safitri, 2018). Sikap informan utama dalam penelitian ini memiliki sikap yang negatif sehingga informan utama tetap melakukan tindakan menggunakan vapor. Hasil dari penelitian menunjukkan bahwa informan utama menganggap vapor lebih aman dari rokok walaupun sedikit terdapat keraguan, vapor sebagai salah satu alat untuk berhenti merokok, dan juga vapor merupakan hal yang baru sehingga dampak dari penggunaan vapor masih belum diketahui walaupun sebenarnya informan utama telah merasakannya.
Adanya personal references membuat informan utama semakin yakin untuk menggunakan vapor. Artinya, perilaku seseorang lebih banyak dipengaruhi oleh orang-orang yang dianggap penting, apabila seseorang itu penting untuknya maka apa yang dikatakan atau diperbuat cenderung untuk dicontoh (Safitri, 2016). Adapun teman dan youtuber merupakan personal references yang sangat kuat bagi informan utama untuk memutuskan menggunakan vapor.

Berdasarkan teori WHO pada penelitian ini membuktikan bahwa tindakan seseorang dapat dipengaruhi oleh beberapa alasan yaitu thoughts and feelings dalam bentuk pengetahuan serta sikap, dan personal references. Hasil penelitian ini menunjukkan bahwa pengetahuan informan utama yang kurang, sikap informan utama yang menunjukkan sikap negatif, dan kuatnya personal references bagi informan utama membuat informan utama tetap melakukan tindakan menggunakan vapor. Sehingga, peneliti mendapatkan beberapa alasan informan utama menggunakan vapor karena adanya varian rasa, mengikuti tren, tertarik pada uap yang dihasilkan dan juga untuk berhenti merokok dan mengurangi penggunaan rokok. 


\section{KESIMPULAN DAN SARAN}

Pengetahuan informan utama yang kurang mengenai dampak dari menggunakan vapor dan mengatakan bahwa vapor memberikan manfaat untuk berhenti merokok menyebabkan informan utama tetap menggunakan vapor. Sikap yang negatif karena informan utama menganggap vapor lebih aman daripada rokok walaupun terdapat keraguan, vapor sebagai salah satu alat untuk berhenti merokok dan juga masih belum mengetahui dampak dari menggunakan vapor padahal sudah merasakan efek dari menggunakan vapor seperti dehidrasi, pusing, dan kecanduan menyebabkan informan utama tetap menggunakan vapor. Personal references memiliki peranan yang sangat kuat khususnya teman dan youtuber untuk memutuskan dalam penggunaan vapor bagi informan utama, namun informan utama tidak mengungkapkan bahwa keluarga menjadi personal references. Tindakan yang dilakukan oleh informan utama yaitu menggunakan vapor mempunyai alasan seperti untuk berhenti merokok dan mengurangi penggunaan rokok, tertarik akan adanya varian rasa cairan vapor dan uap yang dihasilkan bahkan karena mengikuti tren saja.
Masih belum terdapat program terkait penggunaan vapor di Jember saat ini. Sehingga temuan penelitian ini memberikan saran bagi dinas kesehatan dan juga komunitas pengguna vapor untuk saling bekerjasama dengan LSM atau tenaga kesehatan terkait dengan pengadaan sosialisasi terhadap pengguna vapor akan dampak bagi kesehatan yang diakibatkan jika menggunakan vapor guna meningkatkan pengetahuan. Sedangkan, bagi mahasiswa pengguna vapor sebaiknya meningkatkan pengetahuan mengenai penggunaan vapor yang berdampak bagi kesehatan sehingga dapat menjadi sebuah pertimbangan dalam menggunakan vapor.

\section{DAFTAR PUSTAKA}

Allteppos. 2016. Apakah ada Efek Pusing ketika Menggunakan Vaporizer?. Tersedia: Allteppos.com: http://allteppos.co m/apakah-ada-efek-pusing-ketikam enggunakan-vapo rizer/

BPOM RI. 2015. InfoPOM Vol. 16 No.

\section{Jakarta: BPOM}

Brown, J., West, R., Beard, E., Michie, S., Shahab, L. MCNiell, A. 2014. Jurnal Addictive Behaviors. Prevalence and Characteristics of ecigarette users in Great Britain: Findings from a general population survey of smokers Volume 39 Issue 6. ELSEIVER 
Desideria, B. 2016. Journal: Pro dan Kontra di Balik Nikmatnya Isapan Rokok Elektrik. Tersedia: Liputan6.com: http://news.liputan6 .com/read/2549635/journal-prodan-kontradi-baliknikmatnyaisapan-rok okelektrik

DetikHealth. 2014. Diklaim Bantu Proses Berhenti Merokok, Ini Kata Dokter tentang Rokok Elektrik. Tersedia: detik.com: https://health. detik.com/beritadetikhealth/251705 9/diklaim-bantu-proses-berhenti-me rokok-ini-kata-dokter-tentangrokok -elektrik

Erikania, J. 2017. Apakah Vape Mengandung Nikotin seperti Rokok? Tersedia: National Geographic Indonesia: http: //nationalgeographic .grid.id/read/13307311/apakahvape mengandungnikotinsepertirokok? page $=$ all

Indra, M.F., N. Yesi H., dan Utami, S. 2015. Jurnal Online Mahasiswa. Gambaran Psikologis Perokok Tembakau yang Beralih Menggunakan Rokok Elektrik (Vaporizer) Volume 2 No 2. Program Studi Ilmu Keperawatan Universitas Riau.

Johnson, M., CPNP, A., Pennington, N., dan RNC. 2014. Journal of Pediatric Nursing. Adolescent Use of Electronic Cigarette: An Emergent Health Concern for Pediatric Nurses Volume 30 Issue 4. ELSEVIER

Lorensia, A., Yudiarso, A., dan Herwansyah, F. R. 2017. Jurnal of Pharmacy and Chemistry Volume 4
No. 2. Persepsi, Efektifitas, dan Keamanan Penggunaan Rokok Elektrik (E-Cigarette) Oleh Perokok Aktif Sebagai Terapi dalam Smoking Cessation: Mixed Methods dengan Pendekatan Studi Kuantitatif dan Kualitatif. Universitas Surabaya.

Nayir, E., Karacabey, Burak., Kirca, O., dan Ozdogan, M. 2016. Journal of Oncological Science. Electronic Cigarette (E-Cigarette) Volume 2 Issue 1. ELSEVIER

Pisinger, C dan Dossing, M. 2014. Preventive Medicine 69. A Systematic Review of Health Effects of Electronic Cigarettes Volume 69. ELSEVIER

Prasetyo, S.E., 2017. Mewaspadai Peredaran Beragam Narkoba Jenis Baru Vapor Narkoba. Tersedia: Jawapos.com:

https://www.jawapos. com/metro/metropolis/30/01/2017/ mewaspadai-peredaran-beragamnarkoba-jenis-baru-vapor-narkoba

Phua, J., Lin, J.,dan Lim, D.J., 2018. Computers in Human Behavior. Understanding Consumer Engagement with CelebrityEndorsed E-Cigarette Advertising on Instagram. ELSEIVER

Putra, I. G. N. E., Putra, I. M. R., Prayoga, D. G. A. R., dan Astuti, P. A. S. 2017. Proceeding Book 4 th ICTOH 2017. Gambaran Pemahaman, Persepsi, dan Penggunaan Rokok Elektrik pada Siswa Sekolah Menengah Atas di Kota Denpasar. Program Studi 
Kesehatan Masyarakat Fakultas Kedokteran Universitas Udayana.

Ririanty, M. 2011. Jurnal IKESMA Volume 7 Nomor 2. Faktor yang Mempengaruhi Perilaku Seksual Berisiko Anak Jalanan di Kabupaten Jember Propinsi Jawa Timur. Fakultas Kesehatan Masyarakat Universitas Jember.

Setyanti, C.A. 2014. Menyingkap Fakta Keamanan Rokok Elektrik. Tersedia: CNNIndonesia.com: https://www.cnnindonesia.com/gay a-hidup/20141105132553-2559816/ menyingkap-fakta-keamananrokokelektrik

Safitri, M.E., Luthviatin, N., Ririanty, M. 2016. E-Journal Pustaka Kesehatan Volume 4 No. 1. Determinan Perilaku Pasien dalam Pengobatan Tradisional dengan Media Lintah. Fakultas Kesehatan Masyarakat Universitas Jember

Yusepi, T.T. 2017. 4 Risiko Membahayakan Akibat Vape. Tersedia: Liputan6.com: https://ww w.liputan6.com/health/read/313934 3/4risiko-membahayakan-akibat-va pe 